\title{
Oral microbiota in children with type 1 diabetes mellitus
}

Microbiota jamy ustnej u dzieci z cukrzycą typu 1

\author{
${ }^{1}$ Marek Pachoński, ${ }^{2}$ Aleksandra Koczor-Rozmus, ${ }^{2}$ Katarzyna Mocny-Pachońska, ${ }^{2}$ Patrycja Łanowy, \\ ${ }^{3}$ Anna Mertas, ${ }^{4}$ Przemysława Jarosz-Chobot
}

\author{
${ }^{1}$ NZOZ Pachońscy Dental Clinic Marek Pachoński, Tarnowskie Gory, Poland \\ ${ }^{2}$ Department of Conservative Dentistry with Endodontics, Faculty of Medical Science, Medical University \\ of Silesia, Katowice, Poland \\ ${ }^{3}$ Department of Microbiology and Immunology, Faculty of Medical Science, Medical University of Silesia, \\ Katowice, Poland \\ ${ }^{4}$ Department of Children's Diabetology, Medical University of Silesia, Katowice, Poland
}

\begin{abstract}
Introduction: The oral cavity is a unique ecosystem in which the microbiome is formed by the colonization of billions of bacteria, viruses, and fungi.

Aim of the study was to assess the quality and quantity of bacterial microbiota of the oral cavity in children with type 1 diabetes in comparison to healthy children.

Material and methods: The study group consisted of 50 randomly selected type 1 diabetic children aged 10-18 years divided into 2 groups (25 people each) according to the level of diabetes control: well-controlled group (WC) - $\mathrm{HbA}_{1 \mathrm{c}} \leq 7.5 \%$ ) and poorlycontrolled group (PC) $-\mathrm{HbA}_{1 \mathrm{c}}>7.5 \%$. The control group (GC) consisted of 25 randomly selected children with no systemic diseases. The material for microbiological tests was collected as two swabs: one from the bottom of the oral cavity and the other one from the posterior part of the dorsum of the tongue).

Results: The statistical analysis revealed statistically significant differences in the total number of isolated microorganisms between PC and GC (post hoc test $p=0.003$ ) and WC and GC (post hoc test $p<0.001$ ). There were no statistically significant differences in the number of isolated microorganisms between PC and WC $(p=0.195)$.

Conclusions: Oral microbiome in type 1 diabetic children is significantly quantitatively different in comparison to healthy children. There are also visible qualitative differences in the profile of oral microbiota in type 1 diabetic children and healthy children.
\end{abstract}

Key words:

periodontitis, microbiota, dental caries, Candida albicans, type 1 diabetes.

\section{Streszczenie}

Wprowadzenie: Jama ustna stanowi unikalny ekosystem, który kolonizują biliony bakterii, wirusów i grzybów.

Cel pracy obejmował ocenę ilościową i jakościową mikroflory jamy ustnej u dzieci z cukrzycą typu 1 w porównaniu z dziećmi zdrowymi. Materiał i metody: Materiał mikrobiologiczny pobierano w postaci dwóch wymazów: z dna jamy ustnej oraz z grzbietu języka u 50 losowo wybranych dzieci z cukrzycą typu 1 w wieku 10-18 lat. Uczestników badania zakwalifikowano do dwóch grup (po 25 osób każda) w zależności od stopnia wyrównania cukrzycy: z cukrzycą wyrównaną (WC, HBA 1 < 7,5\%) i z cukrzycą niewyrównaną (PC, HBA 1 z 7,5). Grupa kontrolna (GC) obejmowała 25 losowo wybranych zdrowych dzieci w wieku 10-18 lat.

Wyniki: Analiza statystyczna wykazała istotną statystycznie różnicę w całkowitej ilości wyizolowanych szczepów drobnoustrojów pomiędzy grupami PC i GC (post hoc test $p=0,003$ ) and WC i GC (post hoc test $p<0,001$ ). Różnicy tej natomiast nie wykazano pomiędzy grupami PC i WC $(p=0,195)$.

Wnioski: Mikrobiota jamy ustnej dzieci z cukrzycą typu 1 różni się istotnie pod względem ilościowym w stosunku do dzieci zdrowych. Zaobserwowano również wyraźne różnice jakościowe w składzie mikroflory jamy ustnej pomiędzy badanymi dziećmi z cukrzycą typu 1 a zdrowymi.

\section{Słowa kluczowe:}

mikrobiota, cukrzyca typu 1, próchnica zębów, Candida albicans, choroby przyzębia. 


\section{Introduction}

The oral cavity is a unique ecosystem in which teeth, gingival groove, tongue, cheeks, soft and hard palate, and tonsils coexist to create a special environment. It is covered with mucosa, which consists of keratinized or nonkeratinized squamous stratified epithelium, depending on the localization and function. The oral cavity, being an extension of the surrounding external environment, is colonized by billions of bacteria, viruses, and fungi that form the microbiome of the oral cavity. This commensal microbiota coexists in symbiosis with its host, but when an imbalance occurs, the disease develops. This imbalance is called dysbiosis. Dental caries and periodontal diseases, the main dental conditions, are caused by dysbiosis. In addition to the commensal flora in the oral cavity, there also occurs a transient flora, e.g. the intestinal flora, which resides in the oral cavity for a short period of time due to difficulty in acquiring nutrients [1, 2].

The microbiota of the oral cavity is also a risk factor for many systemic diseases such as tumours [3], diabetes [4], cardiovascular diseases [5], sepsis [6], preterm births, and low birth weight of infants [7]. More than 700 species of bacteria were identified with culture-independent approaches, and more than 250 were isolated, cultured, and named [8]. Undoubtedly, new species are still being identified $[9,10]$.

\section{Salivary microbial}

The greatest number and diversity of microbiota are observed in dental plaque, then in saliva, and on the oral mucosa. The dominant fraction of microbiota in the saliva is like that found in the throat and tonsils. In addition, saliva also contains bacteria from supra and subgingival niches. The main types of bacteria noticed in saliva include Actinobacteria, Bacteroidetes, Firmicutes, Fusobacteria, and Proteobacteria [11]. It has been proven that the salivary microbial configuration is more dependent on the influence of the environment than on genetic conditions [12].

\section{Dental plaque}

Dental plaque is a type of biofilm located on the surface of the teeth. There are 2 plaque classifications: supragingival plaque (placed above the gingival margin) and subgingival plaque (below the gingival margin). The composition of the subgingival plaque depends on the balance between health and disease and is associated with periodontal destruction. Microbiological research of this niche focuses mainly on changes in the microbiota that occur during the development of periodontal diseases. In gingivitis, which is an inflammatory process confined to the gum and most often associated with the accumulation of plaque, the dominant microorganisms are: Streptococcus, Actinomycetes, Capnocytophaga, Campylobacter, Eikenella, Fusobacterium, and Prevotella. On the other hand, in the case of periodontitis, which is a chronic inflammatory process involving not only the destruction of the gingiva, but also tooth-supporting tissues (periodontal membrane and alveolar bone), the subgingival microbiota in the course of periodontitis is very complex. Over 400 phenotypes have been isolated from periodontal pockets [13].

\section{Oral mucosa}

Compared with the other parts of the oral cavity, microorganisms existing on the mucosa are few. The dorsum of the tongue is the most colonized, by bacteria associated with halitosis. Among the bacteria on its surface in healthy populations, we can identify Streptococcus salivarius, Rothia mucilaginosa, and unidentified, cultivable species of Eubacterium strain FTB41 [13].

\section{Diabetes mellitus}

Various research studies on the composition of the subgingival bacterial microbiota in diabetics compared to healthy individuals have been performed. However, no clear influence of diabetes on bacterial flora has been demonstrated.

Certain species of bacteria are more common in diabetic patients. However, it is difficult to confirm whether their occurrence is directly related to a change in the subgingival environment or indirectly due to a change in the host's immune response. Diabetic individuals are more prone to chronic periodontitis as a result of hyperglycaemia that alters the subgingival environment such that pathogenic bacteria become dominant. Alternatively, diabetes can alter the host response to plaque, causing more tissue destruction. Considering the elevated glucose level in the subgingival environment and the altered or inhibited host immune response, real differences can be found in the subgingival microbiome in diabetic patients in comparison to healthy individuals [14].

\section{Aim of the study}

The aim of the study was to analyse and compare the composition of bacterial oral microbiota in children with type 1 diabetes and healthy children.

\section{Material and methods}

\section{Characteristics of the research groups}

The study group consisted of 50 randomly selected children aged 10-18 years, who had had type 1 diabetes for at least 5 years. The subjects were patients of the regional diabetic clinic at the Upper John Paul II Silesian Children's Health Centre University Hospital in Katowice, Poland.

Patients from the study group were divided into 2 groups (25 people each) according to their level of diabetes control. The allocation of patients to the groups was based on the qualification criterion, which was the level of glycated haemoglobin $\left(\mathrm{HbA}_{1 \mathrm{c}}\right)$. According to the recommendations of the American Diabetes Association (ADA) and the International Society for Paediatric and Adolescent Diabetes (ISPAD 2014), the threshold value of $\mathrm{HbA}_{1 \mathrm{c}}$ was set at 7.5\% [15]. Patients with good glycaemic control were assigned to the Well Controlled group ( $\mathrm{WC}, \mathrm{HbA}_{1 \mathrm{c}} \leq 7.5 \%$ ). The mean age of the subjects in the WC group was $14.40 \pm 2.0$ years. The group consisted of 
10 girls and 15 boys. Twenty-three patients in this group were using a personal insulin pumps (continuous subcutaneous insulin infusion-CSII) and 2 patients were using insulin pens (multiple daily insulin injection-MDII). The average level of glycated haemoglobin was $6.70 \pm 0.40 \%$. The Poorly Controlled (PC, $\mathrm{HbA}_{1 \mathrm{c}}>7.5 \%$ ) group consisted of patients with poor glycaemic control. The mean age of the subjects in the PC group was $14.92 \pm 1.87$ years. The group consisted of 14 girls and 11 boys. Eighteen patients in this group were using personal insulin pumps (CSII) and 7 were using insulin pens (MDII). The mean glycated haemoglobin level in this group was 8.23 $\pm 0.64 \%$.

The control group (GC) consisted of 25 randomly selected healthy children who were treated at the NZOZ Pachońscy Dental Clinic in Tarnowskie Góry, Poland. The mean age of the subjects was $14.52 \pm 1.29$ years. The group consisted of 13 girls and 12 boys.

The study groups were homogeneous in terms of sex and age ( $\chi^{2}$ Pearson test: $\left.p=0.50, p=0.41\right)$. The study was conducted in the period 2014-2018.

\section{Exclusion criteria from the research}

The following groups were excluded: Patients and/or legal guardians, parents not agreeing to participate in the study, patients not willing to cooperate in the study, and those additionally burdened with other diseases (thyroid diseases, celiac disease, arterial hypertension).

In the control group, the exclusion criteria were diabetes and all systemic disorders, as well as refusal to participate in the study.

The tests were performed anonymously, and each patient was given a code number. The parents or legal guardians of all participants gave their written consent to participate in the study. The research project was approved by the Bioethical Commission of the Silesian Medical University in Katowice (No. KNW / 0022 / KB1 / 26 / I / 14 of 22/04/2014) and conducted in accordance with the latest version of the Helsinki declaration

\section{Collection of the samples to microbiological tests}

The material for microbiological tests was collected from each of the subjects as 2 swabs: one from the bottom of the oral cavity (BOC bacteria) and the other from the posterior part of the dorsum of the tongue (DT bacteria). The swabs were collected using sterile swabs, which were then placed in the transport medium and delivered to the Department of Microbiology and Immunology of the Medical University of Silesia in Zabrze, where the laboratory microbiological tests were carried out. The material was collected in the morning between 08:00 and 10:00 a.m. The participants were asked to attend the examination with an empty stomach and before completing any hygienic procedures in the oral cavity.

\section{Laboratory microbiological tests}

Microbiological tests were carried out using classical methods routinely used in microbiological diagnostics. The material collected from the examined patients was cultured on appro- priate culture media to multiply and then isolate pure microbial cultures. Aerobic bacteria were multiplied on solid medium Columbia agar with a $5 \%$ addition of sheep blood at $37^{\circ} \mathrm{C}$. Anaerobic bacteria were multiplied on Schaedler K3 solid medium with a $5 \%$ addition of sheep blood at $37^{\circ} \mathrm{C}$ in an-aerobic conditions obtained using Biomerieux Genbag Anaer kits (Marcy l'Etoile, France). Candida fungi were multiplied and initially identified using chromogenic medium ChromID Candida from Biomerieux (Marcy l'Etoile, France).

After isolation and multiplication of the cultured strains of microorganisms, their species identification was carried out using the following sets of reagents: ENTEROtest 24 N, NEFERMtest 24 N, STREPTOtest 24, STAPHYtest 24, ANAEROtest 23, OXItest, PYRAtest, and the computer program TNW lite 6.5 for species identification of Erba-Lachema microorganisms (Brno, Czech Republic). The following biochemical tests from Biomerieux (Marcy l'Etoile, France) were also used: Catalysis, Slidex Staph Kit, and API Candida. Execution, reading, and interpretation of the test results were performed in accordance with the recommendations of manufacturers of diagnostic reagent kits.

\section{Statistical analysis}

All statistical analyses were performed using the STATISTICA Version 13 program package (StatSoft, Tulsa, OK, USA), the SciPy module, and the Statsmodels Phyton module. All charts were prepared using Excel (Microsoft Office, Redmond, Washington, USA). Continuous variables between the groups were compared using the Kruskal-Wallis and Mann-Whitney $U$ tests because the analysed variables were not normally distributed.

All statistical analyses were supplemented with the results of 2 post-hoc tests: the Dunn-Bonferroni and Conover tests. To test the differences of nominal variables between the groups, the Pearson chi-square test was used. $P$ values $<0.05$ were considered statistically significant.

\section{Results}

The results are presented in the form of box plots. The upper and lower boundaries of the box determine the first (Q1) and third quartiles (Q3) of the variable distribution, respectively. The line in the centre of the box is the median. Lower and upper whisker indicate the minimum and maximum values. The cultures were assessed according to the number of microbial species. The number of strains of a given species of microorganisms was determined. The authors counted the number of different microorganism strains that were isolated from mucosa of each particular subject per participant for the 3 mentioned groups of children: PC, WC, and GC.

Figure 1 presents the results of the Kruskal-Wallis test used to assess the presence of any significant differences in the number of all bacteria isolated from the bottom of the oral cavity (Bacteria BOC) between all study groups. These differences were shown to be statistically significant $(p<0.001)$, and as such the results of the statistical analysis were supported by 2 of the post-hoc tests: the Dunn-Bonferroni test and 


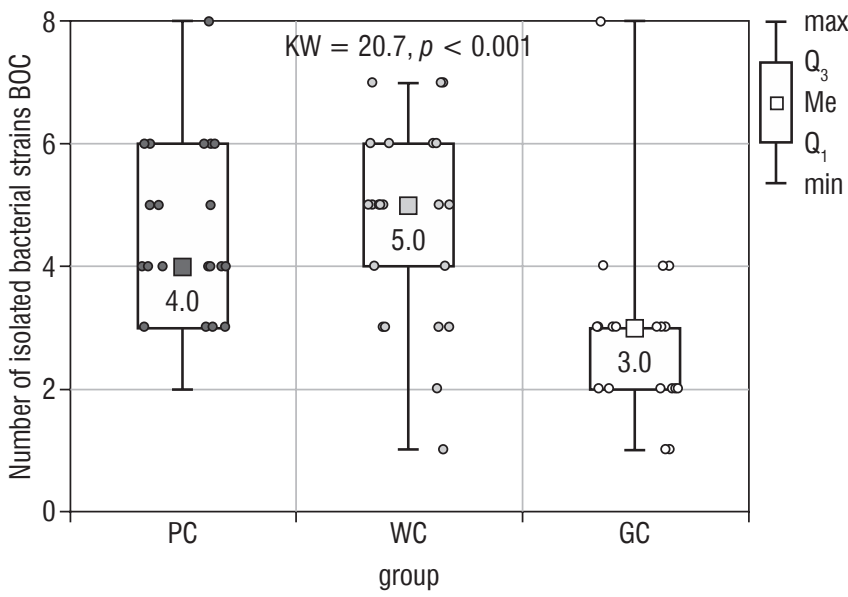

Figure 1. The number of bacterial strains isolated from the bottom of the oral cavity in the study groups of children (KruskalWallis test)

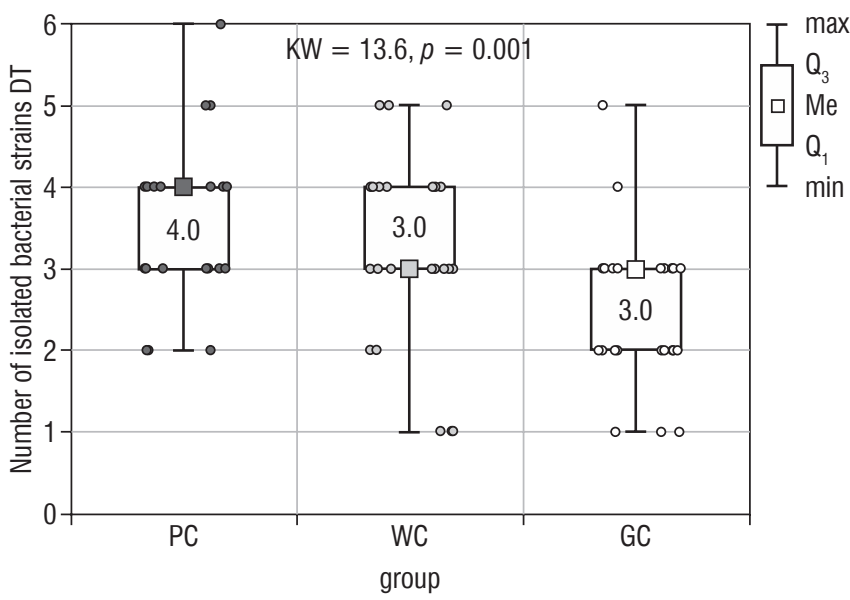

Figure 2. The number of bacterial strains isolated from the dorsum of the tongue in the study groups of children (KruskalWallis test)

the Conover test. Post-hoc analysis revealed that the median number of different strains isolated by BOC swab was significantly lower in the GC group compared to the PC ( $p=0.001)$ and WC groups $(p<0.001)$ (Table I). The obtained median in PC group was 4.0, 5.0 in WC group, and 3.0 in GC group. The highest number of isolated strains of bacteria [8] in one participant was found in the PC and GC groups. In the WC group this value was 7 .

The number of all isolated bacteria from the tongue's dorsum (Bacteria DT) also differed significantly between the examined groups of children (the Kruskal-Wallis test; $p=0.001$; Fig. 2). The results of the Dunn-Bonferroni test showed statistically significant differences between the WC (median 3.0) and GC (median 3.0) groups as well as between the PC (me-
Table I. Results of post hoc tests - number of isolated bacterial strains $(\mathrm{BOC})$

\begin{tabular}{|c|c|c|c|c|}
\hline & \multirow{2}{*}{$\begin{array}{l}\text { Post hoc } \\
p\end{array}$} & \multicolumn{3}{|c|}{ Dunn-Bonferroni } \\
\hline & & PC & WC & $\mathrm{GC}$ \\
\hline \multirow{3}{*}{$\begin{array}{l}\bar{\phi} \\
\text { Oे } \\
\overline{0} \\
0\end{array}$} & PC & & 0.623 & 0.001 \\
\hline & WC & 0.222 & & $<0.001$ \\
\hline & GC & 0.028 & 0.019 & \\
\hline
\end{tabular}

PC - poorly controlled group; WC - well controlled group; GC - control group

Table II. Results of post hoc tests - number of isolated bacterial strains (DT)

\begin{tabular}{|c|c|c|c|c|}
\hline & \multirow{2}{*}{$\begin{array}{l}\text { Post hoc } \\
p\end{array}$} & \multicolumn{3}{|c|}{ Dunn-Bonferroni } \\
\hline & & PC & WC & $\mathrm{GC}$ \\
\hline \multirow{3}{*}{$\begin{array}{l}\overline{0} \\
\text { o } \\
\text { ठ } \\
0\end{array}$} & PC & & 0.368 & 0.001 \\
\hline & WC & 0.166 & & 0.021 \\
\hline & GC & 0.029 & 0.058 & \\
\hline
\end{tabular}

PC - poorly controlled group; WC - well controlled group; GC - control group

dian 4.0) and GC groups. The second post-hoc test revealed the statistically significant difference only between PC and GC groups (Table II). There were no statistical differences between the studied groups of children with diabetes.

The conducted statistical analysis revealed statistically significant differences in the total number of all isolated microorganisms (Bacteria BOC \& DT) between PC and GC groups (Kruskal Wallis test; $p<0.001$; Fig. 3). The highest number of isolated bacterial strains [10] was obtained in the PC group. In the WC and GC groups the value was 9. The medians obtained in the PC, WC, and GC groups were: 6, 7, and 4, respectively. There were no statistically significant differences in the number of isolated microorganisms between the PC and WC groups (Table III). 


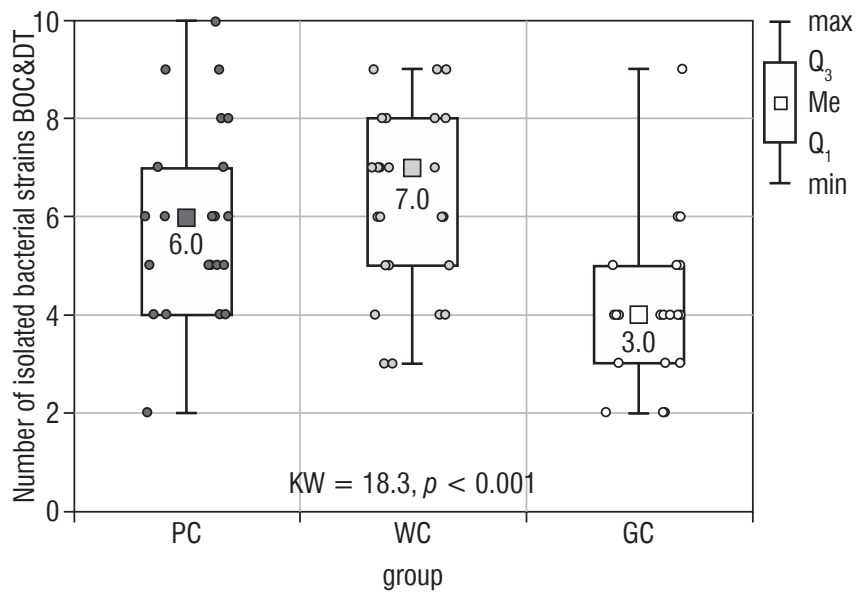

Figure 3. The number of bacterial strains isolated from the bottom of the oral cavity and the dorsum of the tongue in the study groups of children (Kruskal-Wallis test)

As a result of the microbiological examination, the number of total_microorganisms isolated in the PC group was 160 species. In the WC group, 158 microorganisms were cultured, and in the control group 103.

The microorganisms cultured were assigned to the following groups: gram-positive streptococci, gram-negative streptococci, gram-positive coccobacillus, and gram-negative coccobacillus (Table IV).

A separate group isolated during the microbiological examination was the yeast Candida albicans. In the PC group, Candida albicans was isolated in 8 children, in the WC group in 4 diabetic children, and in the GC group in 5 healthy children. The obtained results were not statistically significant $(p=0.21$; Table IV).

The largest group of isolated microorganisms comprised bacteria from the Streptococcus genus. As a result of the study, the following streptococci were cultured: Streptococcus acidominimus, S. cristatus, S. mitis, S. oralis, S. pneumoniae, S. pyogenes, S. sanguinis, and S. salivarius. Statistical calculations demonstrated that the total number of Streptococcus differed significantly between the studied groups $(p=0.018$; Fig. 4). Both of the post hoc tests showed a significant difference between the WC and GC groups (Table V).

Statistical analysis was also performed using the MannWhitney test between the combined groups of children with diabetes (PC \& WC = GD) and the control group. This analysis showed a statistically significantly higher number of bacterial strains isolated from the bottom of the oral cavity and the dorsum of the tongue in the group of children with diabetes (GD) compared to the control group (Mann-Whitney $U$ test; $p<0.001)$. Similar data were obtained with the Streptococcus strain. The GD group was characterized by a significantly higher number of these bacteria as compared to the control group (Mann-Whitney $\cup$ test; $p=0.014$; Figs. 5 and 6).
Table III. Results of post hoc tests - number of isolated bacterial strains (BOC\&DT)

\begin{tabular}{|c|c|c|c|c|}
\hline & \multirow{2}{*}{$\begin{array}{l}\text { Post hoc } \\
p\end{array}$} & \multicolumn{3}{|c|}{ Dunn-Bonferroni } \\
\hline & & PC & WC & GC \\
\hline \multirow{3}{*}{$\begin{array}{l}\bar{D} \\
0 \\
\overline{0} \\
0\end{array}$} & PC & & 0.507 & 0.003 \\
\hline & WC & 0.195 & & $<0.001$ \\
\hline & GC & 0.035 & 0.022 & \\
\hline
\end{tabular}

PC - poorly controlled group; WC - well controlled group; GC - control group

\section{Discussion}

Caries is the most common disease of the oral cavity to which humans are susceptible during their lifetime. This disease not only results in tooth destruction but also affects the pulp and periapical tissues. The most pathogenic bacteria related to the development of caries is Streptococcus mutans. Nevertheless, other bacteria including Streptococcus, Veillonella, Actinomyces, Granulicatella, Leptotrichia, Thiomonas, Bifidobacterium, and Prevotella species were detected in cases of S-ECC $[16,17]$. A significantly higher number of bacteria from the Streptococcus genus were found in the group of children with well-controlled diabetes mellitus compared to healthy children. The samples that were taken from the floor of the oral cavity also revealed differences in the number of described bacteria between both examined WC and PC groups of diabetics. Streptococcus mitis, S. salivarius, S. sanguinis, and S. acidominimus were the most abundantly represented. The study of Janem et al. showed that the microbiological salivary profile of diabetics did not differ statistically significantly from healthy people [18]. Nevertheless, Kampoo et al. noticed distinctly higher levels of Streptococcus and Lactobacillus in diabetics with caries [19].

Our own research also noted an increased amount of Streptococcus mitis in the group of children with type 1 diabetes in comparison to healthy children. This bacterium was isolated in $88 \%$ of children in the PC group, 92\% in the WC group, and $64 \%$ in the control group. Streptococcus mitis is classified as "low $\mathrm{pH}$ streptococcus" - this microorganism can reduce the $\mathrm{pH}$ of glucose broth to below 4.4. Species with similar abilities include S. oralis, S. anginosus, and S. gordonii. The organisms mentioned above are considered to have low carious potential and are listed amongst the primary colonizers of the pellicle. However, their capability of decreasing the $\mathrm{pH}$ level and therefore the occurrence of caries is confirmed by numerous studies $[20,21]$. 
Table IV. Species of oral microbiota isolated from studied groups of children

\begin{tabular}{|c|c|c|c|}
\hline \multirow[t]{2}{*}{ Isolated microorganisms } & \multicolumn{3}{|c|}{ Number of microorganisms } \\
\hline & PC & WC & GC \\
\hline \multicolumn{4}{|l|}{ Gram-positive cocci } \\
\hline Anaerococcus prevotti & - & - & 1 \\
\hline Gemella spp. & 5 & 9 & 1 \\
\hline Globicatella sanguinis & 1 & - & - \\
\hline Microccus spp. & - & 1 & - \\
\hline Peptococcus niger & - & 1 & 1 \\
\hline Streptococcus acidominimus & 7 & 14 & 8 \\
\hline Streptococcus cristatus & - & - & 1 \\
\hline Streptococcus mitis & 22 & 23 & 16 \\
\hline Streptococcus oralis & 4 & 4 & - \\
\hline Streptococcus pneumoniae & - & 2 & 6 \\
\hline Streptococcus pyogenes & - & - & 1 \\
\hline Streptococcus sanguinis & 14 & 12 & 9 \\
\hline Streptococcus salivarius & 16 & 16 & 11 \\
\hline Staphylococcus aureus MSSA & 6 & 4 & 1 \\
\hline Staphylococcus epidermidis MSCNS & 6 & 1 & - \\
\hline Staphylococcus lentus & - & 1 & - \\
\hline Streptococcus warneri & 1 & - & - \\
\hline Sarcina spp. & 1 & - & - \\
\hline \multicolumn{4}{|l|}{ Gram-negative cocci } \\
\hline Nesiseria subflava & 7 & 8 & 1 \\
\hline Neisseria spp. & 16 & 13 & 24 \\
\hline Veillonella parvula & 7 & 12 & 2 \\
\hline \multicolumn{4}{|l|}{ Gram-positive rods } \\
\hline Atopobium parvulum & - & - & 1 \\
\hline Bifidobacterium adolescentis & 6 & - & - \\
\hline Bifidobacterium breve & 1 & 2 & 3 \\
\hline Bifidobacterium dentium & 1 & - & - \\
\hline Bifidobacterium longum & - & 4 & - \\
\hline Eubacterium tortuosum & - & 1 & - \\
\hline Lactobacillus acidophilus & - & 1 & - \\
\hline Lactobacillus catenaformis & - & 1 & 1 \\
\hline
\end{tabular}


Table IV. Species of oral microbiota isolated from studied groups of children (cont.)

\begin{tabular}{|c|c|c|c|}
\hline \multirow[t]{2}{*}{ Isolated microorganisms } & \multicolumn{3}{|c|}{ Number of microorganisms } \\
\hline & PC & WC & GC \\
\hline Lactobacillus fermentum & - & 1 & - \\
\hline Propionibacterium acnes & 1 & 1 & - \\
\hline Propionibacterium propionicum & 1 & 2 & - \\
\hline Pseudoflavonifractor capilosus & - & 1 & 1 \\
\hline Actinomyces israeli & 4 & - & - \\
\hline Actinomyces naes/undi & 4 & 6 & 1 \\
\hline Actinomyces odontolyticus & 2 & 1 & - \\
\hline Actinomyces viscosus & - & 1 & - \\
\hline Blauta producta & - & 1 & - \\
\hline Clostridium barati & - & - & 2 \\
\hline Clostridium chauvoei & 2 & 4 & - \\
\hline Clostridium clostridioforme & 3 & - & - \\
\hline Clostridium histoliticum & 1 & - & 1 \\
\hline Clostridium novyi & - & 1 & - \\
\hline Clostridium perfringens & 4 & - & - \\
\hline Clostridium ramosum & 2 & - & - \\
\hline Clostridium tertium & - & - & 1 \\
\hline \multicolumn{4}{|l|}{ Gram-negative rods } \\
\hline Bacteroides ovatus & - & 1 & - \\
\hline Campylobacter gracilis & - & - & 1 \\
\hline Campylobacter ureolyticus & - & 1 & 2 \\
\hline Capnocytophaga ochracea & 5 & - & - \\
\hline Citrobacter freundii & - & 1 & - \\
\hline Enterobacter cloacae & - & 1 & - \\
\hline Klebsiella oxytoca & - & 1 & - \\
\hline Klebsiella pneumoniae & - & 1 & - \\
\hline Mitsuokella multiacida & 1 & - & - \\
\hline Proteus mirabilis & - & - & 1 \\
\hline Serratia marcescens & 1 & - & - \\
\hline \multicolumn{4}{|l|}{ Fungi } \\
\hline Candida albicans & 8 & 4 & 5 \\
\hline The total number & 160 & 158 & 103 \\
\hline
\end{tabular}




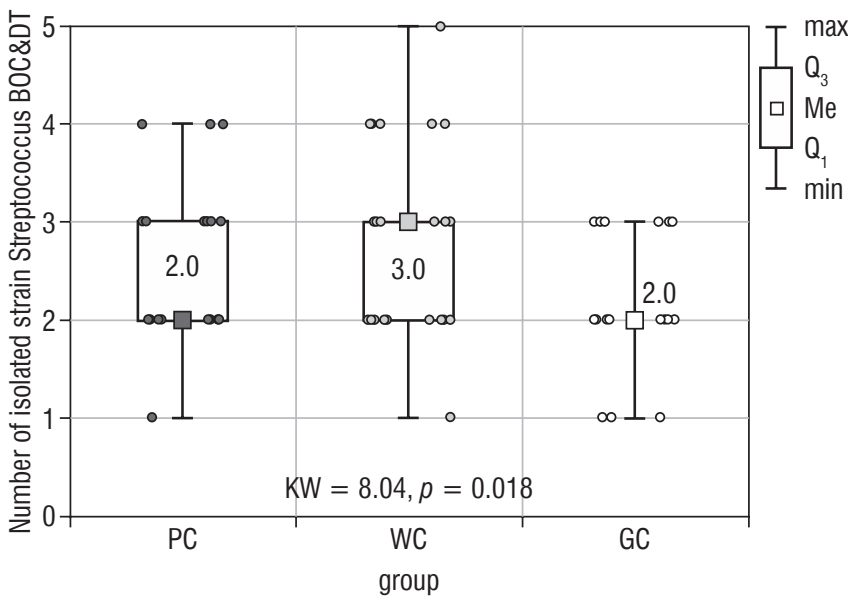

Figure 4. The number of Streptococcus strain isolated from the bottom of the oral cavity and the dorsum of the tongue in the study groups of children (Kruskal-Wallis test)

Candida spp. are commensals detected in the oral cavity among healthy individuals. However, their occurrence and virulence are significantly increased in immunocompromised patients. They may become pathogenic in the case of physiological changes in the host and cause oral candidiasis or invasive systemic infection [22]. Numerous studies identified an increased incidence of Candida spp. in type 1 diabetes, which was closely related to diabetes duration and level of decompensation [23]. Soysa et al. demonstrated that the incidence of that fungus on mucosa may concern $80 \%$ of subjects [24]. The study conducted by the authors did not reveal statistically significant differences in the number of isolated Candida spp. $(p=0.21)$. In the PC group Candida spp. were detected in 8 cases, in the WC group in 6 cases, and in the $\mathrm{GC}$ group in 5 cases. It is certainly related to the fact that the study group consisted of children aged 10-18 years with no periodontitis [25]. Candida albicans strains are often isolated in cases of co-existing diabetes and periodontitis. Sardi et al. revealed that the incidence of Candida albicans reaches $63.63 \%$ among patients with diabetes mellitus and chronic periodontitis [22].

Hintao et al. showed an increased incidence of Treponema denticola, Streptococcus sanguinis, Prevotella nigrescens, Staphylococcus intermedius, and Streptococcus oralis in the subgingival plaque of people with type 2 diabetes compared to healthy people, despite the lack of statistically significant differences in the examined subgingival plaque samples [26].
Table V. Results of post hoc tests - number of Streptococcus strain (BOC\&DT)

\begin{tabular}{|c|c|c|c|c|}
\hline & \multirow{2}{*}{$\begin{array}{l}\text { Post hoc } \\
p\end{array}$} & \multicolumn{3}{|c|}{ Dunn-Bonferroni } \\
\hline & & PC & WC & $\mathrm{GC}$ \\
\hline \multirow{3}{*}{$\begin{array}{l}\bar{\phi} \\
0 \\
\bar{c} \\
0\end{array}$} & PC & & 0.242 & 0.228 \\
\hline & WC & 0.140 & & 0.007 \\
\hline & GC & 0.137 & 0.049 & \\
\hline
\end{tabular}

PC - poorly controlled group; WC - well controlled group; GC - control group

A similar composition of bacterial flora was observed among patients with type $1 \mathrm{DM}$ and in the follow-up of nondiabetic diabetics with periodontitis [27].

\section{Limitations of the study}

The performed research relates to an interesting issue. However, we may be limited by an insufficient number of examined patients. On the other hand, the research was carried out on patients of the largest Diabetology Clinic in Upper Silesia, and applying the inclusion and exclusion criteria also significantly reduced the number of children who could take part in the research. Conducting the study in other regions of Poland to examine the possible influence of environmental factors on oral microbiota would be informative.

\section{Conclusions}

The oral microbiome of children with type 1 diabetes in quantitative terms is significantly different in comparison to healthy children. There are also visible qualitative differences in the profile of oral microbiota in children with type 1 diabetes versus healthy children.

\section{Acknowledgements}

The authors thank all the children and their parents who participated in this study. 


\section{References}

1. Samaranayake L, Matsubara VH. Normal oral flora and the oral ecosystem. Dent Clin N Am 2017; 61: 199-215. doi: 10.1016/j. cden.2016.11.002.

2. Baker JL, Bor B, Agnello M, et al. Ecology of the oral microbiome: beyond bacteria. Trends Microbiol 2017; 5: 362-373. doi: 10.1016/j.tim.2016.12.012.

3. Farrell JJ, Zhang L, Zhou H, et al. Variations of oral microbiota are associated with pancreatic diseases including pancreatic cancer. Gut 2011; 61: 582-588. doi: 10.1136/gutjnl-2011-300784.

4. L e H. Periodontal disease: the six complication of diabetes mellitus. Diabetes Care 1993; 16: 329-334.

5. Figuero E, Sánchez-Beltrán M, Cuesta-Frechoso S, et al. Detection of periodontal bacteria in atheromatous plaque by nested polymerase chain reaction. J Periodontol 2011; 82: 1469-1477. doi: 10.1902/jop.2011.100719.

6. Genco RJ, Graziani F, Hasturk H. Effects of periodontal disease on glycemic control, complications, and incidence of diabetes mellitus. Periodontol 2000 2020; 83: 59-65. doi: 10.1111/prd.1271.

7. Mitchel-Lewis D, Engebretson SP, Chen J, et al. Periodontal infections and pre-term birth: early findings from a cohort of young minority women in New York. Eur J Oral Sci 2001; 109: 34-39. doi: 10.1034/j.1600-0722.2001.00966.x.

8. Paster BJ, Olsen I, Aas JA, et al. The breadth of bacterial diversity on the human periodontal pocket and other sites. Periodontol 2000 2006; 42: 80-87. doi: 10.1111/j.1600-0757.2006.00174.x.

9. Belda-Ferre P, Alcaraz LD, Cabrera-Rubio, et al. The oral metagenome in health and disease. ISME J 2012; 6: 46-56. doi: 10.1038/ ismej.2011.85.

10. Griffen AL, Beall CJ, Campbell JH, et al. Distinct and complex bacterial profiles in human periodonttis and health revealed by 16S pyrosequencing. ISME J 2012; 6: 1176-1185. doi: 10.1038/ ismej.2011.191.

11. Acharya A, Chan $Y$, Kheur S, et al. Salivary microbiome in non-oral disease: A summary of evidence and comentary. Arch Oral Biol 2017; 83: 169-173. doi: 10.1016/j.archoralbio.2017.07.019.

12. Stahringer SS, Clemente JC, Corley RP, et al. Nurture trumps nature in a longitudinal survey of salivary bacterial communities in twins from early adolescence to early adulthood. Genome Res 2012; 22: 2146-2152. doi.org/10.11.1/gr.140608.112.

13. He J, Li Y, Cao Y, et al. The oral microbiome diversity and its relations to human diseases. Folia Microbiol (Praha) 2015; 60: 69-80. doi: 10.1007/s12223-014-0342-2.

14. Ohlrich EJ, Cullinan MP, Leichter JW. Diabetes, periodontitis, and the subgingival microbiota. I Oral Microbiol 2010. doi. 10.3402/jom. v2i0.5818.

15. Di Bartolo P, Nicolucci A, Cherubini V, et al. Young patients with type 1 diabetes poorly controlled and poorly compliant with self- monitoring of blood glucose: can techonology help? Results of the i-New Trend randomized clinical trial. Acta Diabetol 2017; 54 : 393-402. doi: 10.1007/s00592-017-0963-4

16. Tanner ACR, Kent RL, Holgerson PL, et al. Microbiota of severe early childhood caries before and after therapy. J Dent Res 2011; 90: 1298-1305. doi: 10.1177/0022034511421201.

17. Yang F, Zeng X, Ning K, et al. Saliva microbiomes distinguish caries-active from healthy human populations. ISME J 2011; 6: 1-10. doi: 10.1038/ismej.2011.71.

18. Janem WF, Scannapieco FA, Sabharwal A, et al. Salivary inflammatory markers and microbiome in normoglycemic lean and obese children compared to obese children with type 2 diabetes. PLOS ONE 2017; 12: e0183600. https://doi.org/10.1371/journal. pone. 0183600

19. Kampoo K, Teanpaisan R, Ledder RG, et al. Oral bacteria communities in individuals with type 2 diabetes who live in southern Thailand. Applied and Environmental Microbiology 2014; 80: 662-671. doi: 10.1128/AEM.02821-13

20. Van Ruyven FOJ, Linström P, van Houte J, et al. Relationship among mutans streptococci, 'low-pH' bacteria, and iodophilic polysaccharide-producing bacteria in dental plaque and early enamel caries in humans. J Dent Res 2000; 79: 778-784. doi: https://doi.org/10. 1177/00220345000790021201

21. Svensäter G, Borgström M, Bowden GHW, et al. The acid-tolerant microbiota associated with plaque from initial caries and healthy tooth surfaces. Caries Res 2003; 37: 395-403. doi: 10.1159/000073390.

22. Sardi JOC, Duque C, Höfling JF, et al. Genetic and phenotypic evaluation of Candida albicans strains isolated from subgingival biofilm of diabetic patients with chronic periodontitis. Med Mycol 2012; 50: 467-475. doi: 10.3109/13693786.2011.633233.

23. Willis AM, Coulter WA, Hayes JR, et al. Factors affecting the adhesion of Candida albicans to epithelial cells of insulin-using diabetes mellitus patients. J Med Microbiol 2000; 49: 291-293. doi: 10.1099/0022-1317-49-3-291.

24. Soysa NS, Samaranayake LP, Ellepola AN. Diabetes mellitus as a contributory factor in oral candidosis. Diabet Med 2006; 23: 455459. doi: 10.1111/j.1464-5491.2005.01701.x.

25. Pachoński M, Jarosz-Chobot P, Koczor-Rozmus A, et al. Dental caries and periodontal status in children with type 1 diabetes mellitus. Pediatr Endocrinol Diabetes Metab 2020; 26: 39-44. doi: 10.5114/ pedm.2020.93249.

26. Hintao J, Teanpaisan R, Chongsuvivatwong V, et al. The microbiological profiles of saliva, supragingival and subgingival plque and dental caries in adults with and without type 2 diabetes mellitus. Oral Microbiol Immunol 2007; 22: 175-181. doi: 10.1111/j.1399302X.2007.00341.x.

27. Lalla E, Kaplan S, Chang SMJ, et al. Periodontal infection profiles in type 1 diabetes. J Clin Periodontol 2006; 33: 855-862. doi: 10.1111/j.1600-051X.2006.00996.X. 